INKLUSIF Vol 3. No. 2 Desember 2018

\title{
ANALISIS PENGARUH PENGELOLAAN MANAJEMEN DAN KINERJA KOPERASI SYARIAH DALAM MENYALURKAN PEMBIAYAAN PRODUKTIF DI SEKTOR USAHA KECIL
}

\author{
Abdul Aziz ${ }^{1}$ \\ Email: abdulazizmunawar11@gmail.com
}

\begin{abstract}
The fundamental problems faced by the small business trade sector in Indonesia are the lack of access to capital sources and the weak of the role of financial institutions services. Microfinance institutions which be expected tend to more dominant in consumptive financing rather than productive financing. While sharia microfinance institutions do not act optimally. Not yet know how the contribution of the sharia cooperative management in development sharia cooperative performance and its effect in increasing productive financing distribution to empower small business trade sector in Cirebon.

The research method used is a quantitative method using statistics, both descriptive and inferential statistics with Path Analysis as the analysis knife.

Kata Kunci: Small Business Trade, Sharia Cooperative Performance, Productive Financing Distribution.
\end{abstract}

\begin{abstract}
ABSTRAK
Permasalahan mendasar yang dihadapi sektor perdagangan usaha kecil di Indonesia adalah kurangnya akses pada sumber permodalan dan lemahnya peranan pelayanan lembaga keuangan. Lembaga keuangan mikro yang diharapkan justru cenderung lebih dominan pada pembiayaan konsumtif daripada pembiayaan produktif. Sementara lembaga keuangan mikro syariah belum berperan secara optimal. Belum diketahui bagaimana kontribusi manajemen koperasi syariah dalam pengembangan kinerja koperasi dan efeknya dalam meningkatkan penyaluran pembiayaan produktif guna memberdayakan sektor perdagangan usaha kecil di Cirebon.

Metode penelitian yang digunakan adalah metode kuantitatif dengan menggunakan statistik, baik statistik deskriptif maupun statistik inferensial dengan Analisis Jalur (Path Analysis) sebagai pisau analisisnya.

Kata Kunci: Perdagangan Usaha Kecil, Manajemen Koperasi Syariah, Penyaluran Pembiayaan Produktif.
\end{abstract}

\footnotetext{
${ }^{1}$ Dosen Pascasarjana IAIN Syekh Nurjati dan Dosen Fakultas Syari'ah dan Ekonomi Islam IAIN Syekh Nurjati Cirebon.
} 
INKLUSIF Vol 3. No. 2 Desember 2018

\section{PENDAHULUAN}

\section{A. Latar Belakang}

Sektor usaha kecil merupakan sektor yang penting dalam menggerakan perekonomian nasional. Terlihat dari sumbangannya terhadap Produk Domestik Bruto (PDB) nasional yang telah mencapai 56,5\%. Keunggulan sektor usaha kecil Unit Mikro Kecil Menengah(UMKM) sebagai sektor domestik yang mampu menggerakan perekonomian nasional adalah karena ketergantungannya yang kuat terhadap muatan lokal.

Menurut catatan Bank Indonesia, ${ }^{2}$ Unit Usaha Kecil Menengah (UMKM) menggunakan sumber daya dalam negeri baik sumber daya manusia, bahan baku dan peralatan, sehingga usaha kecil tidak tergantung pada impor. Selain itu, hasil produksi sektor usaha kecil lebih ditujukan untuk memenuhi pangsa pasar dalam negeri, sehingga tidak tergantung kepada kondisi perekonomian negara lain. Oleh karena itu, sektor inilah yang paling tahan terhadap ancam krisis global beberapa waktu yang lalu.

Sabirin $^{3}$ menilai bahwa daya tahan usaha kecil (UMKM) di masa krisis tercipta karena usaha kecil tidak banyak memiliki ketergantungan pada faktor eksternal, seperti utang dalam valuta asing dan bahan baku impor dalam melakukan kegiatannya. Dengan keunggulan yang spesifik antara lain berupa kandungan lokal yang besar dalam kegiatan produksi, orientasi pemasaran di dalam negeri, dan harga yang terjangkau oleh konsumen, usaha kecil merupakan bagian yang sangat penting di dalam perekonomian nasional. Melihat pada potensi Usaha Kecil Menegah (UKM) inilah maka salah satu strategi pemulihan ekonomi nasional yang ditempuh Pemerintah dewasa ini adalah memberdayakan UKM.

Perkembangan jumlah unit UKM periode 2006 sampai dengan 2009 mengalami peningkatan sebesar 15,40\% (tidak termasuk usaha mikro), yaitu 509.365 unit di tahun 2006 menjadi 587.808 unit di tahun 2009. Pada periode yang sama, jumlah unit usaha kecil yang berdiri masih mendominasi sekitar 99,21\% dari keseluruhan unit bisnis usaha kecil, menengah dan besar yang berdiri di Indonesia.

Menurut Bryant et.al, ${ }^{4}$ usaha kecil juga memiliki angka pertumbuhan penyerapan tenaga kerja paling tinggi. Dari tahun 2006 sampai dengan 2009, penyerapan tenaga kerja usaha kecil tumbuh $12,15 \%$ dari angka 3.139.711 ke 3.521.073 tenaga kerja. Sementara itu, penyerapan tenaga usaha menengah mengalami sedikit penurunan dibanding-kan dengan tahun 2006, yaitu turun $0,78 \%$ dari angka 2.698 .743 ke angka 2.677 .565 tenaga kerja. Usaha besar mengalami pertumbuhan penyerapan tenaga kerja, yaitu tumbuh $10,93 \%$ dari angka 2.411 .181 ke angka 2.674.671 tenaga kerja.

Kebutuhan akan lembaga keuangan mikro berbasis syariah begitu penting, maka perlu ada peningkatkan kinerja koperasi syariah itu sendiri. Astuti dalam penelitiannya yang diterbitkan pada Jurnal Penelitian ${ }^{5}$ menjelaskan, karena itu upaya koperasi syariah sebagai lembaga mediasi (pendampingan) pembiayaan skala mikro harus dibarengi dengan adanya

\footnotetext{
${ }^{2}$ Bank Indonesia, "Outlook Perbankan Syari'ah," 2013. 4-5.

${ }^{3}$ Syahril Sabirin, Perjuangan Keluar Dari Krisis Pemikiran Dr. Syahril Sabirin (Yogyakarta: BPFE, 2003). 485.

${ }^{4}$ et. al Donald Bryant, "Potensi Perusahaan UKM Untuk Go Publik," 2011.31.

${ }^{5}$ Donald Bryant.133.
} 
peningkatan kinerja LKMS melalui (1) peningkatan kesehatan LKMS, dan (2) peningkatan keberpihakan pemerintah melalui regulasi dan lembaga keuangan mikro termasuk di dalamnya BMT atau LJKS (Lembaga Jasa Keuangan Syariah).

Namun demikian, koperasi syariah BMT-BMT banyak yang tidak berhasil dalam menjalankan fungsinya sebagai lembaga keuangan mikro syariah yang mampu berkinerja baik, disamping tidak menjalankan prinsip-prinsip di atas, juga karena paling tidak ada dua permasalahan pokok yang mendasar, yaitu permasalahan internal dan permasalahan eksternal. Menurut Soesilo ${ }^{6}$, kelemahan dan kekurangan koperasi, termasuk di dalamnya koperasi syariah dalam menggapai kesejahteraan anggotanya dikarenakan lemahnya aspek permodalan sebagai permasalahan internal dan eksternal. Limbong, ${ }^{7}$ manajemen koperasi dilakukan secara terbuka, terutama untuk anggotanya. Keterbukaan manajemen koperasi dititikberatkan pada pelaksanaan fungsi pertanggungan jawaban pengurus koperasi.

Faktor eksternal disamping dari kurangnya keterampilan anggota, juga berasal dari iklim usaha. Di lapangan, masih sering didengar, betapa meraka harus menghadapi suatu kondisi ketidakpastian ketersediaan bahan baku utama dan bahan tambahan. Demikian pula masalah penggunaan peralatan dan teknologi yang sangat sederhana. Sebagian pasar mereka cenderung bersifat oligopoli. Kepemilikan modal sangat rendah.

Menurut Soesilo, ${ }^{8}$ bahwa setidaknya kelemahan koperasi berpangkal dari: (1) masih sulitnya sumber modal; teknologi tepat, sulitnya akses pasar dan informasi bisnis oleh ekonomi rakyat, dan (2) masih rendahnya kualitas kelembagaan, manajemen dan organisasi koperasi.

Namun demikian, Sinaga et.al. ${ }^{9}$ dalam penelitiannya menemukan problematika koperasi dalam memberdayakan unit usaha ekonomi serba terbatas dan sarat dengan kelemahankelemahan, terutama dalam hal SDM anggota dan SDM pengelola koperasi serta kelemahan permodalan internal koperasi. Maka, wajar jika eksistensi koperasi juga terkena imbas dari perubahan iklim bisnis tersebut.

Kendalah-kendala seperti ini dapat ditemui pada koperasi-koperasi syariah pada umumnya dan di Kabupaten dan Kota Cirebon, pada khususnya. Misalnya, dari 12 Koperasi Syariah (KBMT), hanya 5 KBMT yang dapat menyelenggarakan Rapat Anggota Tahunan (RAT). Ini dapat dipahami karena mayoritas KBMT tidak dikelola dengan manajemen modern. Padahal, menurut Limbong ${ }^{10}$ bahwa manajamen koperasi seharusnya menjadi manajemen partisipatif dimana di dalamnya mampu memperlihatkan terjadinya interaksi antar unsur dalam manajemen koperasi. Masing-masing unsur ada uraian tugas (job description). Pada setiap unsur manajemen memiliki lingkup keputusan (decision) yang berbeda, meskipun tetap ada pada lingkup keputusan yang dilakukan secara bersama (shared decision areas).

\footnotetext{
${ }^{6}$ M. Iskandar Soesilo, Dinamika Gerakan Koperasi Indonesia (Jakarta: Graha Pena dan Wahana Semesta Intertemedia RIMBOOKS, 2008).149.

${ }^{7}$ Bernhard Limbong, Pengusaha Koperasi Memperkokoh Fondasi Ekonomi Rakyat (Jakarta: Margaretha Pustaka, 2012).102.

${ }^{8}$ M. Iskandar Soesilo, Dinamika Gerakan Koperasi Indonesia.154.

${ }^{9}$ Donald Bryant, "Potensi Perusahaan UKM Untuk Go Publik."3.

${ }^{10}$ Bernhard Limbong, Pengusaha Koperasi Memperkokoh Fondasi Ekonomi Rakyat.85.
} 
Sedikit dari koperasi syariah yang ada di Cirebon, diantara koperasi syariah yang mampu melaksanakan prinsip-prinsip manajemen adalah Koperasi Pesantren (Kopontren) Al-Ishlah Bobos Kab. Cirebon. Kopontren ini mampu melaksanakan prinsip-prinsip manajemen modern. Di antaranya, mampu melaksanakan visi dan misi koperasi baik sebagai organisasi maupun sebagai perusahaan. Juga mampu menyusun program kerja dengan kegiatan-kegiatan usaha yang lebih spesifik. ${ }^{11}$

Dengan demikian, peran manajemen koperasi yang berbasis pada pendanaan, keanggotaan, dan pembiayaan sangatlah penting dalam meningkatkan kinerja koperasi dalam rangka mendorong penyaluran pembiayaan produktif yang mampu memberdayakan sektor perdagangan usaha kecil, secara spesifik perlu diteliti mengingat masih kurangnya penelitianpenelitan yang fokus pada bidang ini.

\section{B. Metode Penelitian}

Metode penelitian yang digunakan adalah metode kuantitatif dengan menggunakan statistik, baik statistik deskriptif maupun statistik inferensial dengan Analisis Jalur (Path Analysis) sebagai pisau analisisnya.

Statistik deskriptif merupakan prosedur-prosedur mengorganisasikan dan menyajikan informasi dalam satu bentuk yang dapat digunakan dan dapat dikomunikasikan atau dapat dimengerti. Karena berhubungan dengan pencatatan, pengorganisasian, dan peringkasan informasi dari data numerik. Sedangkan statistik inferensial adalah metode analisis yang digunakan untuk mengetahui atau mengukur derajat hubungan atau perbedaan antara dua variabel atau lebih. ${ }^{12}$

Obyek dari penelitian ini adalah BMT-BMT di Cirebon, dimana data diperoleh dengan melakukan survey terhadap BMT-BMT tersebut.

\section{PEMBAHASAN}

\section{A. Tinjauan Konseptual}

Istilah koperasi diartikan sebagai sekumpulan anggota yang didirikan bersama untuk memproduksi barang dan jasa yang dikendalikan atas partisipasi anggota, individu para petani, rumah tangga, berbagi risiko dan keuntungan karena sebagai pemilik perusahaan ekonomi itu sendiri. $^{13}$

Dalam perspektif Islam, koperasi yang menjunjung asas kebersamaan dan kekeluargaan dapat dipandang sebagai bentuk syirkah ta'awuniyah yang bermakna bekerja sama dan tolong menolong dalam kebaikan, dan dalam operasionalnya tidak berhubungan dengan aktivitas riba, maysir (judi), dan gharar (spekulan), maka lengkapnya keselarasan koperasi dengan nilai-nilai Islam. $^{14}$

\footnotetext{
${ }^{11}$ Urip Triyono.et.al, Kopontren Al-Ishlah Cirebon Mensinergikan Potensi Koperasi Di Tengah Lingkungan Yang Berubah (Jakarta: Erlangga, 2006).350.

${ }^{12}$ Ulber Silalahi, “Metode Penelitian Sosial Kuantitatif," 2015.336.

${ }^{13}$ Irish Co-operative Organisation Society, Starting a Co-Operative : Introduction, 2011.9.

${ }^{14}$ Masyarakat Ekonomi Syari'ah (MES), “Direktori Bisnis Dan Ekonomi Syari'ah” (Jakarta, 2011).36.
} 
Koperasi syariah dapat dipadankan dengan kata syirkah dalam bahasa Arab yang berarti kemitraan, sama halnya dengan kata cooperation (Inggris) yang berarti kerjasama. Jadi, koperasi syariah berbentuk syirkah (kerjasama), wadah kemitraan, kekeluargaan antara 2 (dua) orang atau lebih sesuai dengan prinsip Islam. ${ }^{15}$ Dengan kata lain, dari segi konsepsi koperasi syariah tidaklah berbeda dengan koperasi umum dari sisi bentuk dan jenisnya. Perbedaannya pada prinsip dan produk-produk yang dikembangkannya.

Menurut an-Nabhani, ${ }^{16}$ apa pun bentuknya, koperasi adalah konsep kapitalis yang tidak syar'i. la tidak sependapat bahwa koperasi dapat di rujuk/padankan dengan syirkah dalam Islam. Karena koperasi adalah salah satu jenis perseroan kapitalis. Alasannya, karena koperasi tetap merupakan bentuk perseroan, meskipun namanya adalah koperasi. Koperasi adalah salah satu jenis perseroan kapital yang berupa penanaman modal antara sekelompok orang yang melakukan kesepakatan antarsesama mereka, untuk mengadakan kerjasama sesuai dengan kondisi tertentu mereka.

Koperasi biasanya beranggotakan sejumlah orang, bisa berjumlah tujuh, atau lebih sedikit, ataupun lebih banyak. Tidak mungkin hanya beranggotakan dua orang. Koperasi seperti ini ada dua macam, yaitu:

1. Berbentukperseroan yang mempunyai founder shares, yang memungkinkan tiap orang untuk menjadi persero (anggota koperasi) karena ikut andil dalam founder shares tersebut.

2. Berbentuk perseroan yang tidak mempunyai founder shares, dimana untuk menjadi anggotanya adalah dengan membayar iuran tahunan yang ditetapkan oleh koperasi secara umum, tiap tahun.

Prinsip dasar koperasi pada umumnya berasal dari sistem kapitalis yang mendasarkan pada sistem bunga, yang kemudian diadopsi istilahnya menjadi syirkah ta'awuniyah menjadi koperasi syariah yang bebas dari riba dengan menerapkan prinsip bagi-rugi hasil (profit and loss sharing) dan qard-hasan system (QHS) sebagai salah satu prinsip pokok dalam kegiatan bisnisnya. ${ }^{17}$ Jadi, Koperasi Syariah adalah koperasi yang kegiatan usahanya bergerak di bidang pembiayaan, investasi, dan simpanan sesuai dengan pola bagi-rugi hasil (syariah).

\section{B. Kerangka Pemikiran}

Pemusatan pengembangan koperasi di bidang pembiayaan di Cirebon pada dasarnya merupakan upaya merekonstruksi model dalam rangka upaya dan layanan untuk mendukung pengembangan, pengendalian dan operasi Koperasi Syariah di Cirebon pada suatu pusat agar diperoleh efektivitas dan efisiensi dalam pengembangan koperasi bidang pembiayaan.

Penyaluran dana lewat pembiayaan dari koperasi syariah diharapkan menggunakan pola penyaluran pembiayaan produktif, bukan hanya untuk konsumtif. Pola penyaluran dana untuk

\footnotetext{
${ }^{15}$ Muhammad, Lembaga-Lembaga Keuangan Umat Kontemporer (Yogyakarta: UII Press, 2007).93.

${ }^{16}$ An-Nabhani Kazmi, "Probable Differences Among the Paradigms Governing Conventional and Islamic Approach to Management," International Journal of Management Concept and Philosophy 1, no. 4 (2005): $263-89$.

${ }^{17}$ M. Fahim Khan, Human Resources Mobilization Through The Profit-Loss Sharing Based Financial System (JeddahSaudi Arabia: IDB-IRTI, 1992).96.
} 
sektor konsumtif bagi negara maju/industri jauh lebih baik dibandingkan dengan negara berkembang. Sebab, penguasaan mereka terhadap teknologi, akses pasar, infrastruktur perdagangan internasional lebih dominan. Kartu kredit, misalnya, berapa milyar dolar per bulan yang akan tersedot ke luar negeri sebagai principal Visa, Master, Electron, Cirrus, Maestro, Diners Club dan sebagai kartu kredit lainnya.

Melalui pola pembiayaan produktif pada sektor riil akan membantu memberdayakan UMKM, namun masalah permodalan, baik keterbatasan kepemilikan modal maupun kesulitan dalam mengakses sumber pembiayaan, sampai saat ini masih merupakan kendala bagi Usaha Mikro dan Kecil (UMK) dalam menjalankan dan mengembangkan usahanya. Permasalahan lain yang dihadapi oleh UMK di bidang pembiayaan antara lain:

1. Masih rendahnya kredibilitas UMK dari sudut analisis perbankan;

2. Persyaratan administrasi dan prosedur pengajuan usulan pembiayaan yang rumit dan birokratis;

3. Adanya persyaratan kesediaan jaminan berupa agunan yang sulit untuk dipenuhi oleh UMK

4. Informasi yang kurang merata (asimetri) tentang layanan perbankan dan lembaga keuangan yang dapat di manfaatkan oleh UMK,

5. Keterbatasan jangkauan pelayanan dari lembaga keuangan, khususnya perbankan.

Berdasarkan landasan teori di atas, maka kerangka pemikirannya dapat digambarkan sebagai berikut:

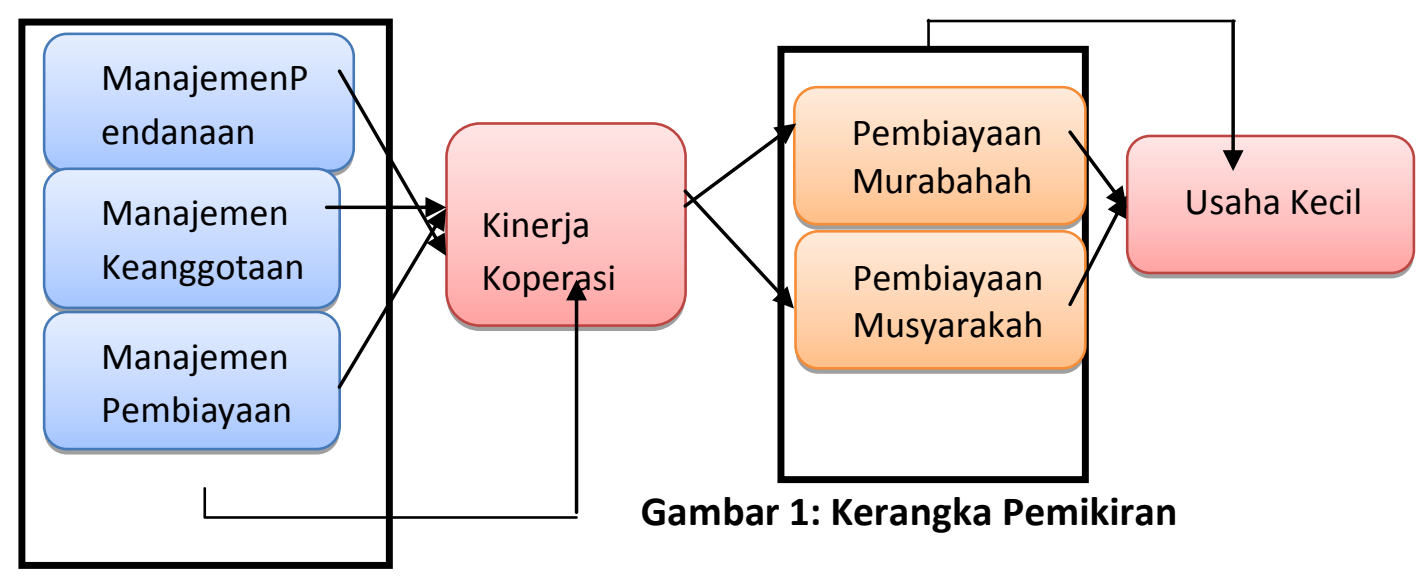

Dari kerangka pemikiran di atas, maka dapat dijelaskan empat model penelitiannya sebagai berikut:

Model hubungan fungsional antar variabel yang ditunjukkan model penelitian di atas diformulasikan sebagai fungsi linear. Model fungsional yang dianalisis adalah:

1. Modelpengaruh manajemen pendanaan, keanggotaan, dan pembiayaan terhadap kinerja koperasi syariah;

2. Model pengaruh kinerja koperasi terhadap penyaluran pembiayaan murabahah;

3. Modelpengaruh kinerja koperasi terhadap penyaluran pembiayaan musyarakah; 
4. Model pengaruh pembiayaan murabahah dan musyarakah terhadap sektor perdagangan usaha kecil.

Keempat model dianalisis secara rekursif sebagai model rangkaian hubungan kausal yang saling berkaitan. ${ }^{18}$ Adapun masing-masing model dapat diformulasikan sebagai berikut:

1. Model Pengaruh Peran Manajemen Pendanaan, Keanggotaan dan Pembiayaan terhadap Kinerja Koperasi Syariah (Model I)

$Y=f\left(X_{1}, X_{2}, X_{3}\right)$

dimana:

$Y=$ Kinerja Koperasi Syariah

$\mathrm{X}_{1}=$ Manajemen Pendanaan

$\mathrm{X}_{2}=$ Manajemen Keanggotaan

$\mathrm{X}_{3}=$ Manajemen Pembiayaan

2. Model Pengaruh Kinerja Koperasi Syariah terhadap Penyaluran Pembiayaan Murabahah (Model II)

$Z_{1}=f\left(Y^{\wedge}\right)$

dimana:

$\mathrm{Z}_{1}=$ Penyaluran Pembiayaan Murabahah

$\mathrm{Y}^{\wedge}=$ Kinerja Koperasi Syariah, sebagai hasil estimasi dari Model I (model pengaruh Manajemen Pendanaan, Keanggotaan dan Pembiayaan terhadap Kinerja Koperasi Syariah)

3. Model Pengaruh Kinerja Koperasi Syariah terhadap Penyaluran Pembiayaan Musyarakah (Model III)

$Z_{2}=f\left(Y^{\wedge}\right)$

dimana:

$\mathrm{Z}_{2}=$ Penyaluran Pembiayaan Musyarakah

$Y^{\wedge}=$ Kinerja Koperasi Syariah, sebagai hasil estimasi dari Model I (model pengaruh Manajemen Pendanaan, Keanggotaan dan Pembiayaan terhadap Kinerja Koperasi Syariah)

4. Model Pengaruh Penyaluran Pembiayaan Murabahah dan Musyarakah terhadap Sektor Perdagangan Usaha Kecil (Model IV)

$Z_{3}=f\left(Z_{1} \wedge, Z_{2} \wedge\right)$

dimana:

$\mathrm{Z}_{3}=$ Sektor Perdagangan Usaha Kecil

$\mathrm{Z}_{1}{ }^{\wedge}=$ Penyaluran Pembiayaan Murabahah, sebagai hasil estimasi dari Model II (model pengaruh Kinerja Koperasi Syariah terhadap Penyaluran Pembiayaan Murabahah)

$\mathrm{Z}_{2}{ }^{\wedge}=$ Penyaluran Pembiayaan Musyarakah, sebagai hasil estimasi dari Model III (model pengaruh Kinerja Koperasi Syariah terhadap Penyaluran Pembiayaan Musyarakah)

Seluruh formulasi model menunjukkan bentuk hubungan kausal secara rekursif antara manajemen pendanaan, keanggotaan dan pembiayaan terhadap kinerja koperasi syariah,

\footnotetext{
${ }^{18}$ Silalahi, “Metode Penelitian Sosial Kuantitatif." 434.
} 
INKLUSIF Vol 3. No. 2 Desember 2018

dampaknya pada penyaluran pembiayaan murabahah dan musyarakah, implikasinya pada sektor perdagangan usaha kecil.

\section{Hipotesis Penelitian}

Berdasarkan perumusan masalah dan kerangka pemikiran, hipotesis dalam penelitian ini adalah:

1. Peran manajemen pendanaan, keanggotaan dan pembiayaan koperasi syariah diduga berpengaruh secara simultan terhadap kinerja koperasi syariah. Secara parsial, peran manajemen pendanaan, keanggotaan dan pembiayaan koperasi syariah berpengaruh positif terhadap kinerja koperasi syariah.

2. Kinerja koperasi syariah diduga berpengaruh positif terhadap penyaluran pembiayaan murabahah.

3. Kinerja koperasi syariah diduga berpengaruh positif terhadap penyaluran pembiayaan musyarakah.

4. Penyaluran pembiayaan murabahah dan musyarakahdiduga berpengaruh secara simultan terhadap sektor perdagangan usaha kecil. Secara parsial, penyaluran pembiayaan murabahah dan musyarakah berpengaruh positif terhadap sektor perdagangan usaha kecil.

\section{Hasil Penelitian}

Berdasarkan hasil penelitian, dalam pembahasan ini diinterpretasikan hasil pengujian hipotesis untuk masing-masing model keberpengaruhannya. Secara umum, pengaruh variabelvariabel penyebab terhadap variabel akibat yang diteliti memiliki arah pengaruh sebagaimana diprediksikan oleh teori. Selain itu diidentifikasi variabel dominan dalam model yang bertujuan agar dapat diketahui variabel apa yang semestinya diprioritaskan untuk ditingkatkan, karena pengaruhnya yang paling kuat, dalam rangka peningkatan atau optimalisasi kualitas variabel akibat.

Berdasarkan hasil analisis model secara keseluruhan, faktor-faktor penyebab yang diteliti secara mayoritas merupakan faktor-faktor yang berpengaruh terhadap variabel akibat (endogen). Dalam model kinerja koperasi syariah, manajemen koperasi syariah - yaitu: manajemen pendanaaan, manajemen keanggotaan, dan manajemen pembiayaan merupakan faktor-faktor yang dominan relatif jika dibandingkan pengaruh faktor-faktor lainnya yang tidak diteliti. Sedangkan dalam model lainnya, pengaruh faktor-faktor lainnya yang tidak diteliti lebih dominan. Secara ringkas, hasil penelitian tentang pengaruh antar variabel dapat dilihat pada gambar di bawah ini. 


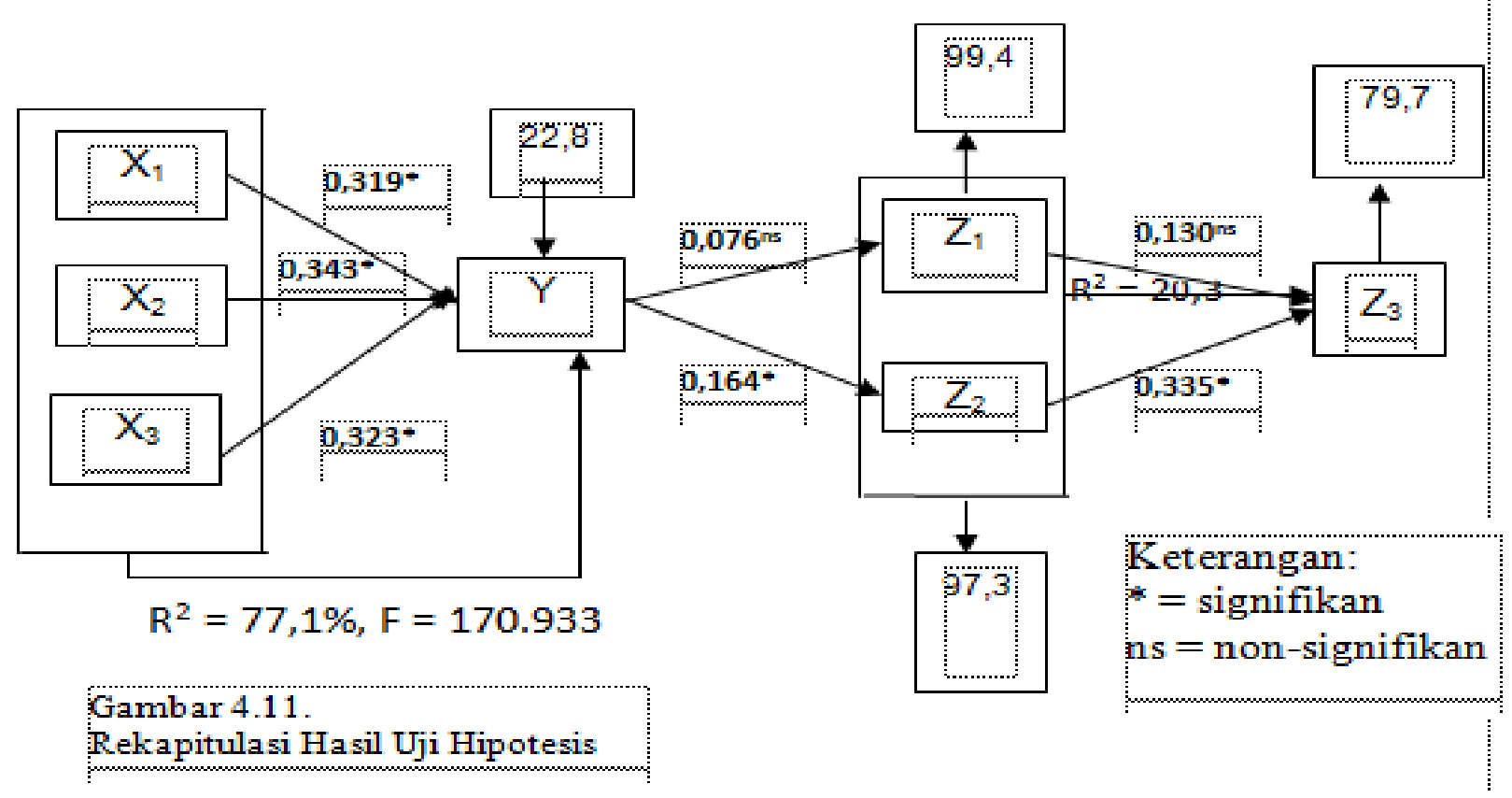

\section{Keterangan:}

1. Pengaruh Manajemen Pendanaan, Manajemen Keanggotaan dan Manajemen Pembiayaan Secara Simultan dan Parsial terhadap Kinerja Koperasi Syariah

Hasil penelitian menunjukkan bahwa manajemen pendanaan, manajemen keanggotaan dan manajemen pembiayaan berpengaruh signifikan secara simultan dan parsial terhadap kinerja koperasi syariah. Arah pengaruh dari manajemen pendanaan, manajemen keanggotaan dan manajemen pembiayaan terhadap kinerja koperasi syariah adalah positif, yaitu sesuai dengan prediksi teoritisnya.

Dibandingkan faktor-faktor luar, seluruh faktor yang diteliti (manajemen pendanaan, manajemen keanggotaan dan manajemen pembiayaan) secara simultan memberikan kontribusi pengaruh yang dominan terhadap kinerja koperasi syariah. Secara parsial, kontribusi pengaruh lebih disumbangkan oleh manajemen keanggotaan sehingga dalam pencapaian kinerja koperasi syariah, manajemen keanggotaan merupakan variabel dominan. Walaupun demikian, pengaruh manajemen pendanaan, manajemen keanggotaan dan manajemen pembiayaan relatif masih lemah.

Adanya pengaruh yang positif dari manajemen pendanaan, manajemen keanggotaan dan manajemen pembiayaan secara simultan terhadap kinerja koperasi syariah menunjukkan kesesuaian hasil penelitian dengan teori tentang pentingnya kualitas manajemen dalam pencapaian kinerja koperasi, baik dalam pendanaan, keanggotaan maupun pembiayaan. Meningkatnya kemampuan pengurus dalam mengelola pendanaan, keanggotaan dan pembiayaan akan mendorong semakin meningkatnya kinerja koperasi.

\section{Pengaruh Kinerja Koperasi Syariah terhadap Penyaluran Pembiayaan Murabahah}

Hasil penelitian menunjukkan bahwa kinerja koperasi syariah tidak berpengaruh positif secara signifikan terhadap penyaluran pembiayaan murabahah. Walaupun demikian, arah 
pengaruh dari kinerja koperasi syariah terhadap penyaluran pembiayaan murabahahadalah positif, yaitu sesuai dengan prediksi teoretisnya.

Dibandingkan faktor yang diteliti (Kinerja Koperasi Syariah), faktor-faktor-faktor luar memberikan kontribusi pengaruh yang dominan terhadap penyaluran pembiayaan murabahah. Adapun tidak signifikannya pengaruh positif dari kinerja koperasi syariah terhadap penyaluran pembiayaan murabahah menunjukkan bahwa kontribusi kinerja koperasi syariahdalam peningkatan penyaluran pembiayaan murabahahmasih sangat rendah yang mengindikasikan bahwa penyaluran pembiayaan murabahah pada koperasi syariah di Kabupaten dan Kota Cirebon belum efektif sebagaimana yang diharapkan. Hal ini karena orientasi pengurus koperasi syariah yang masih lebih memprioritaskan penyaluran pembiayaan musyarakah dibandingkan murabahah.

\section{Pengaruh Kinerja Koperasi Syariah terhadap Penyaluran Pembiayaan Musyarakah}

Hasil penelitian menunjukkan bahwa kinerja koperasi syariah berpengaruh positif secara signifikan terhadap penyaluran pembiayaan musyarakah. Sebagaimana untuk penyaluran pembiayaan murabahah, arah pengaruh dari kinerja koperasi syariahterhadap penyaluran pembiayaan musyarakahjuga positif, yaitu sesuai dengan prediksi teoretisnya.

Dibandingkan faktor yang diteliti (Kinerja Koperasi Syariah), faktor-faktor-faktor luar memberikan kontribusi pengaruh yang dominan terhadap penyaluran pembiayaan musyarakah. Walaupun signifikan, kontribusi kinerja koperasi syariah dalam peningkatan penyaluran pembiayaan musyarakahmasih rendah yang mengindikasikan bahwa efektivitas penyaluran pembiayaan musyarakah pada koperasi syariah di Kabupaten dan Kota Cirebon masih rendah dan perlu dioptimalkan. Walaupun pengurus koperasi syariah lebih memprioritaskan penyaluran pembiayaan musyarakah dibandingkan murabahah, namun kemampuan pengurus untuk memberdayakan kinerja koperasi dalam rangka peningkatan pembiayaan produktif perlu ditingkatkan.

\section{Pengaruh Penyaluran Pembiayaan Murabahah dan Musyarakah Secara Simultan dan Parsial terhadap Sektor Perdagangan Usaha Kecil}

Hasil penelitian menunjukkan bahwa penyaluran pembiayaan murabahah dan penyaluran pembiayaan musyarakahberpengaruh signifikan secara simultan dan parsial terhadap sektor perdagangan usaha kecil. Arah pengaruh dari penyaluran pembiayaan murabahah dan penyaluran pembiayaan musyarakah terhadap sektor perdagangan usaha kecil adalah positif, yaitu sesuai dengan prediksi teoretisnya.

Dibandingkan seluruh faktor yang diteliti (Penyaluran Pembiayaan Murabahah dan Penyaluran Pembiayaan Musyarakah) secara simultan, faktor-faktor luar memberikan kontribusi pengaruh yang dominan terhadap sektor perdagangan usaha kecil. Secara parsial, diantara penyaluran pembiayaan murabahah dan penyaluran pembiayaan musyarakah, kontribusi pengaruh lebih disumbangkan oleh penyaluran pembiayaan musyarakah. Dengan demikian dalam pemberdayaan sektor perdagangan usaha kecil, penyaluran pembiayaan 
musyarakahmerupakan variabel dominan. Walaupun demikian, pengaruh penyaluran pembiayaan musyarakah relatif masih lemah.

Adanya pengaruh yang positif dari penyaluran pembiayaan murabahah dan penyaluran pembiayaan musyarakahsecara simultan terhadap sektor perdagangan usaha kecilmenunjukkan kesesuaian hasil penelitian dengan teori tentang pentingnya peran pembiayaan produktif dari lembaga keuangan mikro dalam pemberdayaan sektor perdagangan usaha kecil. Meningkatnya kemampuan pengurus dalam menyalurkan pembiayaan produktif, baik murabahah maupun musyarakah, merupakan determinan penting bagi keberdayaan dan perkembangan sektor perdagangan usaha kecil.

\section{PENUTUP}

Berdasarkan pembahasan di atas, maka permasalahan pokok dapat disimpulkan sebagai berikut:

Manajemen(tata kelola) yang baik, seperti manajemen pendanaan, manajemen keanggotaan dan manajemen pembiayaan sangat berarti dalam mendukung peningkatan kinerja koperasi syariah. Terlebih, manajemen keanggotaan terbukti efektif dan sangat berarti dalam memerankan keunggulan kinerja koperasi syariah.

Kinerja koperasi syariah sudah menunjukkan peningkatan yang berarti, namun pengaruh kinerja koperasi tersebut belum efektif, seperti yang diharapkan terhadap meningkatnya penyaluran pembiayaan murabahah.

Dalam mendorong penyaluran pembiayaan musyarakah bagi kinerja koperasi syariah sudah menunjukkan langkah yang berarti.

Keberadaan koperasi syariah telah menciptakan hal yang sangat bermanfaat bagi sektor perdagangan usaha kecil, terutama dari segi penyaluran pembiayaan murabahah dan musyarakah.

\section{DAFTAR PUSTAKA}

An-Nabhani Kazmi. "Probable Differences Among the Paradigms Governing Conventional and Islamic Approach to Management." International Journal of Management Concept and Philosophy 1, no. 4 (2005): 263-89.

Bank Indonesia. “Outlook Perbankan Syari'ah," 2013.

Bernhard Limbong. Pengusaha Koperasi Memperkokoh Fondasi Ekonomi Rakyat. Jakarta: Margaretha Pustaka, 2012.

Donald Bryant, et. al. "Potensi Perusahaan UKM Untuk Go Publik," 2011.

M. Fahim Khan. Human Resources Mobilization Through The Profit-Loss Sharing Based Financial System. Jeddah-Saudi Arabia: IDB-IRTI, 1992.

M. Iskandar Soesilo. Dinamika Gerakan Koperasi Indonesia. Jakarta: Graha Pena dan Wahana Semesta Intertemedia RIMBOOKS, 2008.

Masyarakat Ekonomi Syari'ah (MES). “Direktori Bisnis Dan Ekonomi Syari'ah.” Jakarta, 2011.

Muhammad. Lembaga-Lembaga Keuangan Umat Kontemporer. Yogyakarta: UII Press, 2007.

Silalahi, Ulber. "Metode Penelitian Sosial Kuantitatif," 2015.

Society, Irish Co-operative Organisation. Starting a Co-Operative : Introduction, 2011. 
INKLUSIF Vol 3. No. 2 Desember 2018

Syahril Sabirin. Perjuangan Keluar Dari Krisis Pemikiran Dr. Syahril Sabirin. Yogyakarta: BPFE, 2003. Urip Triyono.et.al. Kopontren Al-Ishlah Cirebon Mensinergikan Potensi Koperasi Di Tengah Lingkungan Yang Berubah. Jakarta: Erlangga, 2006. 